\title{
Management of pikeperch stocking in Lake Balaton: effect of season, area, fish size and method of release on the rate and distribution of recaptures
}

\author{
András Specziár ${ }^{1, *}$ and Béla Turcsányi ${ }^{2}$ \\ ${ }^{1}$ Balaton Limnological Institute, MTA Centre for Ecological Research, Klebelsberg K. u. 3, 8237 Tihany, Hungary \\ ${ }^{2}$ Balaton Fish Management Non-Profit Ltd., Horgony u. 1, 8600 Siófok, Hungary
}

\begin{abstract}
Pikeperch Sander lucioperca is an economically important fish which depleted populations need intensive management and supplemental stocking. We aimed to assess the relative influence of various pikeperch stocking strategies in Lake Balaton, Hungary, and tested 60 stocking set-ups (two seasons $\times$ three lake areas $\times$ shore $v s$. offshore release $\times$ five size groups) by releasing 3000 tagged yearlings. Anglers reported data of 522 recaptures within four years after stocking. Recapture rate was highest in stocking of the most productive lake area, increased with fish size, was higher in shore than offshore releases, but did not differed between stocking seasons. Fish stocked to oligotrophic areas travelled longer distances and dispersed more than those stocked to the mesotrophic area. Fish size had little effect, whereas season and method of stocking had no effect on dispersal of fish. To conclude, in pikeperch, autumn stocking with large yearlings released directly from the shore is recommended over other set-ups. Stocking quotas may be concentrated in space in low productivity areas, but should be dispersed between multiple sites in food rich areas to attain complete dispersal. This study provides a framework for testing fisheries management alternatives and behaviour of stocked fish in intensively utilized habitats.
\end{abstract}

Keywords: angling / fisheries management / mark and recapture / Sander lucioperca / stocking strategy

Résumé - Gestion de l'empoissonnement de sandre dans le lac Balaton: effet de la saison, de la localisation, de la taille du poisson et de la méthode de déversement sur le taux et la distribution des recaptures. Le sandre Sander lucioperca est un poisson économiquement important dont les populations appauvries ont besoin d'une gestion intensive et d'un empoissonnement de soutien. Nous avons cherché à évaluer l'influence relative de diverses stratégies d'empoissonnement de sandre dans le lac Balaton, en Hongrie, et nous avons testé 60 configurations d'ensemencement (deux saisons $\times$ trois zones lacustres $\times$ zone riveraine $\times$ zone de remise à l'eau au large $\times$ cinq groupes de taille) en relâchant 3000 animaux d'un an marqués. Les pêcheurs à la ligne ont apporté des données sur 522 poissons recapturés dans les quatre ans suivant le déversement. Le taux de recapture était le plus élevé dans la zone lacustre la plus productive, il augmentait avec la taille des poissons, était plus élevé sur le rivage que dans les eaux hauturières, mais ne différait pas d'une saison à l'autre. Les poissons déversés dans les zones oligotrophes ont parcouru de plus longues distances et se sont dispersés davantage que ceux déversés dans la zone mésotrophe. La taille du poisson a eu peu d'effet, alors que la saison et la méthode de mise à l'eau n'ont eu aucun effet sur la dispersion du poisson. Pour conclure, pour le sandre, il est recommandé de faire des empoissonnements d'automne avec de grands alevins de l'année relâchés directement du rivage plutôt que d'autres solutions. Les quotas de mise en charge peuvent être concentrés dans l'espace dans des zones à faible productivité, mais devraient être dispersés entre plusieurs sites dans des zones riches en nourriture pour parvenir à une dispersion complète. Cette étude fournit un cadre pour tester les solutions alternatives en matière de gestion des pêches et le comportement des poissons déversés dans les habitats intensivement utilisés.

\footnotetext{
*Corresponding author: specziar .andras@okologia.mta.hu
} 


\begin{abstract}
Mots-clés : pêche à la ligne / gestion des pêches / marquage et capture / Sander lucioperca / stratégie
\end{abstract} d'empoissonnement

\section{Introduction}

Pikeperch Sander lucioperca is a characteristic piscivorous fish in majority of Eurasian lowland freshwater and brackish habitats (Craig, 2000) and has been introduced also outsides its native area because of its high economic value and angling preference (Hickley and Chare, 2004). On the other hand, due to overexploitation of adults and loss of natural spawning and nursery areas reproductive success of pikeperch populations is falling and now often fails to meet ecological and economic demands (Saulamo and Thoresson, 2005; Specziár and Erös, 2016). Exposure of pikeperch recruitment to adverse human impacts is also enhanced by the high sensitivity of spawning success, and early life and first wintering survival of this species to year-to-year variations of environmental conditions (Ruuhijärvi et al., 1996; Lappalainen et al., 2009). Therefore, there is an increasing need to compensate these adverse effects by stocking of aquaculture-reared individuals (Hansson et al., 1997; Abdolmalaki and Psuty, 2007).

In Lake Balaton, native pikeperch as is the main piscivorous species, plays an important role in the food web (Bíró, 1997) and, besides the common carp Cyprinus carpio, is the second most preferred angling fish. Because of its high rate of harvesting (Weiperth et al., 2014; Specziár and Erős, 2016), an early-life dietary bottleneck (Specziár, 2005, 2011) and high rate of predation and cannibalisms related juvenile mortality (Specziár, 2010), maintaining the pikeperch population requires regular stocking. Although commercial fishery, which harvested 2-237 (mean: 83) tons of pikeperch per year between 1901 and 2011 has been stopped in Lake Balaton since 2014, but anglers still put a heavy pressure on the population. For a long time, four to six weeks old and $3-5 \mathrm{~cm}$ standard length $(S L)$ long fingerlings were stocked in an annual amount of $1-1.5$ million individuals. This stocking strategy however has failed because: pikeperch of this size encounter inappropriate feeding conditions in the lake, and accordingly, have poor survival rate (Specziár, 2010); and in addition, annual stocking quotas, which were determined mainly on the basis of easily accessible amount of pond-reared fries rather than based on population dynamics models, proved to be negligible ( $\mathrm{ca}$. two to three orders of magnitude less!) compared even to the lowest approximation of abundance of the natural recruitment regarding the same size group (4221323 million ind. in the lake in May between 2000 and 2008; Specziár, 2010). Therefore, currently pikeperch stocking directions appoint the release of 60000 ind. (or $6000 \mathrm{~kg}$ ) pikeperch yearlings annually into Lake Balaton. However, given the large area of the lake, and correspondingly, the huge number of stocked individuals needed to recruit into adulthood for an effective management compared to the limited amount of financial resources (i.e. income from angling licences) and capacity of appropriate rearing ponds in the region, a strong motivation has arisen from fisheries managers and angling associations to study principles of an effective stocking strategy in pikeperch, following the same approach used in the common carp recently (Specziár and Turcsányi, 2014).

In fisheries oriented stocking programmes, most important indicators of efficiency are the recapture rate, distribution of recaptures in space and time, and size of fish at recapture in relation to resources invested (i.e. number of fish stocked and cost of the project; Hansson et al., 1997; Patterson and Sullivan, 2013). Variability of survival between released stocks is one of the most important factors influencing the recapture rate. In the temperate region, fish stocked in spring generally have better chance to survive than those stocked before the winter (Kennedy et al., 1982; Vostradovský, 1991). Whereas, because pikeperch is especially sensitive to handling at high temperatures, thus its summer stocking is quite risky (Hansson et al., 1997). It was also found that post-stocking survival and recapture rate correlate positively with size of the fish at release (Kennedy et al., 1982; Fielder, 1992; Johnson et al., 1996; Michaletz et al., 2008). In relation to the variability of habitat quality and food resources as well as fisheries interest, place of stocking can also influence survival and recapture rates (Vostradovský, 1991; Michaletz et al., 2008; Balfry et al., 2011; Specziár and Turcsányi, 2014). Movement and distribution of the released fish was also found to depend on various individual traits and environmental factors; distribution may vary between sizegroups and sexes (Young et al., 1999; Stuart and Jones, 2006; Specziár and Turcsányi, 2014), between pond reared and wild captured and re-released indigenous individuals (Bolland et al., 2009), and across stocking habitats (Specziár and Turcsányi, 2014; Andersson et al., 2015). However, although pikeperch is an important commercial and sport fish and is stocked extensively into natural freshwater and brackish ecosystems, there is still limited information on the effect of different stocking strategies on its recaptures in natural waters.

Accordingly, objectives of the present study were to investigate how the rate and distribution of pikeperch recaptures by anglers vary with the season (i.e. spring and autumn), lake area (i.e. Keszthely, Szemes and Siófok basins), method (i.e. shore and offshore releases) and fish size of stocking in Lake Balaton. We predicted that: (i) recapture rate will be higher in spring than autumn stockings, will be positively affected by fish size at release, and will be similar across stocking areas and methods; (ii) mean time between the release and recapture will be shorter in spring than autumn stockings (which is trivial because pikeperch fishing is inconsiderable during the winter), will be correlated negatively with size of fish at release, and will be similar across stocking areas and methods; (iii) fish will travel longer distances and; (iv) recaptures will cover larger areas in autumn and central (Szemes) basin stockings than in other release set-ups, movement of fish will be positively related to size of fish at release, but distribution of pikeperch will not differ between stocking methods. 
Table 1. Specifications of stocking trials including season, area and method of release, water $\left(T_{w}\right)$ and air $\left(T_{a}\right)$ temperatures, number $\left(N_{r}\right)$, standard length $(S L)$ and body mass $(M)$ of pikeperch released and total number of reported recaptures by anglers within 1460 days after release $\left(N_{1460 \text { days }}\right)$ in Lake Balaton, Hungary.

\begin{tabular}{|c|c|c|c|c|c|c|c|c|c|c|c|c|}
\hline \multicolumn{11}{|c|}{ Release } & \multicolumn{2}{|c|}{ Recapture } \\
\hline No. & Date & Area & Method & $T_{w}\left({ }^{\circ} \mathrm{C}\right)$ & $T_{a}\left({ }^{\circ} \mathrm{C}\right)$ & $N_{r}$ & $\begin{array}{l}S L(\mathrm{~mm}) \\
\text { Mean } \pm \mathrm{SD}\end{array}$ & Range & $\begin{array}{l}M(\mathrm{~g}) \\
\text { Mean } \pm \mathrm{SD}\end{array}$ & Range & $N_{1460}$ days & $\%$ \\
\hline 1. & 05.12 .2012 & Keszthely & Shore & 3.2 & 4.7 & 250 & $246 \pm 25$ & $185-300$ & $201 \pm 65$ & $72-385$ & 59 & 23.6 \\
\hline 2. & 05.12 .2012 & Keszthely & Offshore & 3.2 & 4.7 & 250 & $251 \pm 27$ & $185-310$ & $217 \pm 70$ & $79-413$ & 61 & 24.4 \\
\hline 3. & 05.12 .2012 & Szemes & Shore & 3.2 & 4.7 & 250 & $249 \pm 24$ & $190-305$ & $221 \pm 71$ & $93-419$ & 58 & 23.2 \\
\hline 4. & 06.12 .2012 & Szemes & Offshore & 3.2 & 5.1 & 250 & $250 \pm 28$ & $185-305$ & $209 \pm 75$ & $73-407$ & 48 & 19.2 \\
\hline 5. & 05.12 .2012 & Siófok & Shore & 3.2 & 4.7 & 250 & $249 \pm 25$ & $185-295$ & $222 \pm 70$ & $82-382$ & 40 & 16.0 \\
\hline 6. & 05.12 .2012 & Siófok & Offshore & 3.2 & 4.7 & 250 & $250 \pm 26$ & $180-300$ & $215 \pm 70$ & $76-380$ & 40 & 16.0 \\
\hline 7. & 08.03 .2013 & Keszthely & Shore & 6.3 & 12.0 & 250 & $239 \pm 26$ & $180-306$ & $209 \pm 85$ & $61-419$ & 58 & 23.2 \\
\hline 8. & 08.03 .2013 & Keszthely & Offshore & 6.3 & 12.0 & 250 & $238 \pm 23$ & $180-290$ & $197 \pm 70$ & $61-373$ & 57 & 22.8 \\
\hline 9. & 08.03 .2013 & Szemes & Shore & 6.3 & 12.0 & 250 & $238 \pm 22$ & $180-290$ & $207 \pm 70$ & $67-398$ & 46 & 18.4 \\
\hline 10. & 11.03 .2013 & Szemes & Offshore & 8.1 & 7.4 & 250 & $239 \pm 25$ & $170-290$ & $192 \pm 68$ & $52-360$ & 17 & 6.8 \\
\hline 11. & 11.03 .2013 & Siófok & Shore & 8.1 & 7.4 & 250 & $239 \pm 24$ & $170-290$ & $192 \pm 67$ & 74-357 & 19 & 7.6 \\
\hline 12. & 11.03 .2013 & Siófok & Offshore & 8.1 & 7.4 & 250 & $239 \pm 25$ & $180-290$ & $189 \pm 70$ & $75-356$ & 19 & 7.6 \\
\hline Total & & & & & & 3000 & & & & & 522 & 17.4 \\
\hline
\end{tabular}

\section{Materials and methods}

\subsection{Study area}

Lake Balaton is the largest shallow lake (surface area: $593 \mathrm{~km}^{2}$; mean depth: $3.2 \mathrm{~m}$ ) in Central Europe, located at $46^{\circ} 42^{\prime}-47^{\circ} 04^{\prime} \mathrm{N}, 17^{\circ} 15^{\prime}-18^{\circ} 10^{\prime} \mathrm{E}$ and $104.8 \mathrm{~m}$ above sea level. The lake is oligo-mesotrophic with mean annual chlorophyll- $a$ concentrations of $3.6-18.7 \mathrm{mg} \mathrm{m}^{-3}$ (Istvánovics et al., 2007). At present, only $47 \%$ of the lake shore is in a natural or seminatural state and these sections are covered by reed grass Phragmites australis. Submerged macrophytes occur sparsely in the littoral zone. A majority of the lake area $(>85 \%)$ is largely homogeneous open water providing mainly zooplankton and benthic chironomids as food for fishes. This area is inhabited by a species-poor fish assemblages dominated by bleak, Alburnus alburnus, common bream, Abramis brama, razor fish, Pelecus cultratus and introduced hybrid Asian carp, Hypophthalmichthys molitrix $\times H$. nobilis. The littoral zone is more heterogeneous and inhabited by a diverse fish assemblage including the main game fish of the lake, the common carp (Specziár et al., 2013) which species is socked regularly in high quantity (Specziár and Turcsányi, 2014). The main piscivorous fish of Lake Balaton is the pikeperch.

Lake Balaton is visited by about 40000-60000 anglers annually, who fish primarily for common carp and other omnivorous cyprinid species using different ledgering techniques, typically from the shore and less often from boat. Pikeperch is also a much-preferred game fish which capture is allowed most of the year except the close season between 1 March and 30 April, and at the present individuals above $350 \mathrm{~mm} \mathrm{SL}$ (size of maturation is $270-320 \mathrm{~mm} \mathrm{SL}$ ) may be kept by anglers up to maximum of three individuals per day. Pikeperch is mainly fished from boats (there is no data about the ratio of boat fishing) in the open water although some moles of larger boat harbours pushing out into the deep water are also effective angling places for this species. Pikeperch anglers also prefer ledgering with live or dead bait fish, most often with bleak; however, spin fishing with different plastic lures is also applied rarely. Angling effort is distributed quite evenly along the entire lake area at coarse scale and in all seasons. Fishing effort varies seasonally, peaking in summer and decreasing to a very low level in winter.

\subsection{Tagging and release of fish}

In December 2012 and March 2013, altogether 3000 largesized one-summer old ( $0+$ age-group), pikeperch were tagged with Floy ${ }^{\circledR}$ FD-68BC T-Bar Anchor Tags $(2 \times 38 \mathrm{~mm}$; www. floytag.com) of orange colour and marked with unique tag numbers as well as the name and address of the Balaton Fish Management Non-Profit Ltd. In Lake Balaton a special care is taken for avoiding any adverse genetic effect like loss of diversity and genetic drift that long term stocking programs could cause when alien genetic strains or strongly selected mother stocks are used for recruiting (Hansen, 2002; Vandersteen et al., 2012). Therefore, similarly to the ordinary practice in the lake, stocked experimental fish were random semi-natural progeny of the Lake Balaton population. Artificial plastic spawning nests were placed into the Siófok basin of the lake and as the pikeperch had spawned, the nests covered with eggs were transported to the fish farm of the Balaton Fish Management Non-Profit Ltd. and placed into rearing ponds. Larvae hatched and reared on natural diet including various zooplankters and prey fishes up to one year in these ponds. Tagging was performed in the fish farm, near the pond from which experimental fish were obtained by seine netting. The whole tagging procedure and the experimental design was mostly identical to that applied previously in the common carp mark and recapture program with success (Specziár and Turcsányi, 2014). This experimental design models all realistic variates of pikeperch stocking in Lake Balaton, and in addition, supports comparability between the 
behaviour of stocked common carp and pikeperch. Only fish in good condition and with no visible signs of disease or injury were used. Fish were anesthetized in groups in a $0.1 \mathrm{~g} \mathrm{l}^{-1}$ solution of clove oil prior to tagging. Each fish was measured for $S L$ and body mass $(M)$ to the nearest $1 \mathrm{~mm}$ and $1 \mathrm{~g}$, respectively. In order to ensure the best possible tag retention, all tags were inserted by the same long-experienced person (B. Turcsányi, with 20 years of tagging experience) between the pterygiophores of the dorsal fin with a Floy ${ }^{\circledR}$ tagging gun (www.floytag.com; Booth and Weyl, 2008). Then, tagged fish were transported to the stocking site or the nearest harbour (for offshore stocking) by tanker truck in oxygenated water, at a biomass density of $<60 \mathrm{~kg} \mathrm{~m}^{-3}$ (each experimental group of 250 individuals was transported in a separate tank filled with $1 \mathrm{~m}^{3}$ culture pond water).

Tagged fish were released in late autumn (5-6 December) and in early spring ( 8 and 11 March), at three lake areas (Keszthely, Szemes and Siófok basins) and both from the shore and offshore at standard locations, and corresponding to 12 stocking trials with 250 individuals in each (Tab. 1, Fig. 1). Before their release, fish were acclimated to ambient water temperature and checked again for viability. Bottom of each tank was checked for lost tags. No post-handling tag loss and injury were observed. At shore sites, fish were released to the water directly from the tanker truck through a flexible tube. For offshore stocking, tagged fish were taken by a boat equipped with tanks suitable for safely carrying fish, and then fish were released to the water $2 \mathrm{~km}$ offshore by buckets.

\subsection{Recapture of fish and data processing}

Tagged fish were recaptured and reported by the anglers. Aims of the study and a guide of how the tagged fish should be processed and reported were published in written and electronic media as well as supplemented to each angling licence. However, we did not communicated any information about the study design with the anglers, including date and size at which fish were released. We asked anglers to report (either by mail, email or phone) each tagged fish irrespective of its size, but after measurement undersized fish (i.e. $<350 \mathrm{~mm} S L$ ) were to be released back into the lake. We also asked information about the date and location (i.e. nearest settlement and street, estimated distance from the closest unambiguous geographical point or GPS coordinate) of the catch and the size (either $S L$ or $M$, preferably both) of the fish at capture. Anglers were distinctly instructed to indicate if they were not able to provide precise data and were rewarded identically. Ambiguous data were excluded from the analyses. In order to certify the recapture, anglers were asked to cut the tag and send it (by mail or personally) to the Institute. Accordingly, multiple recaptures could not be monitored. Since it has been found that an adequate rewarding significantly increases reporting rate (Sackett and Catalano, 2017), thus we provided a bonus to the next annual fishing licence $(4000 \mathrm{HUF} \approx 13$ EUR of worth, which is about one half of the average daily net wage in Hungary) for each reported recaptures. Note that in this study rewarding was offered only to increase reported sample size and not to approach complete $(100 \%)$ reporting.

Distribution of recaptures within the lake and watercourse distances between release sites and recapture sites was

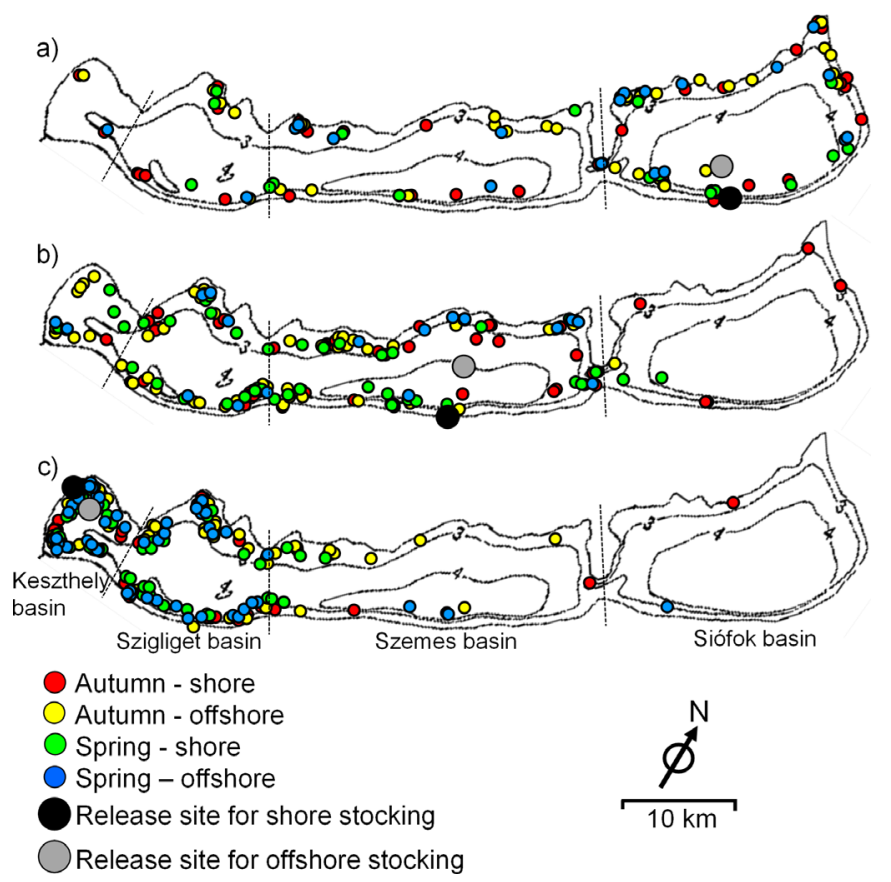

Fig. 1. Map of Lake Balaton (Hungary) with indication of its main basins. Location of each recaptured tagged pikeperch is indicated by stocking trials for fish released at Siófok (a), Szemes (b) and Keszthely (c), in autumn and spring, and from shore and offshore. Note that some recaptures located very close to each other, and thus their scores are overlapping on the plot.

processed with MapSource version 6.16.3 software (Garmin Ltd.; www.garmin.com) using the NaviGuide Hungary version 6.51 map layer (Navi-Gate Ltd.; www.garmin.hu). Further, in order to assess the spatial effect (i.e. positive influence on angling success) of each release strategy, we calculated shore line ranges covered by the first 50,75 and $90 \%$ of recaptures according to their distance from the release point either along the northern, southern or total shore line of the lake.

\subsection{Statistical analysis}

Tagged pikeperch were classified into five size groups based on their $M(\leq 150 \mathrm{~g}, 151-200 \mathrm{~g}, 201-250 \mathrm{~g}, 251-300 \mathrm{~g}$ and $>300 \mathrm{~g}$ ) and fish size was included to release variables (Tab. 2). Accordingly, we could evaluate variability in pikeperch recaptures among 60 different release strategies based on four potential predictor variables (two seasons $\times$ three lake areas $\times$ two methods of release $\times$ five fish size groups) except for hypothesis (iv) where the available sample size did not support the inclusion of fish size into the analysis.

Evaluation of recapture data of this study are based on assumptions that reporting rate (i.e. number of reports sent per number of actually captured tagged fish) was similar for all size-groups, capture season and lake area, and that tag retention rate did not vary between releasing strategies. Reported recapture rate (thereafter "recapture rate") and the distribution of recaptures in time and space were tested for the effect of release factors (i.e. season, lake area, method of release and fish $M$ group) by using analysis of variance (ANOVA) to the second degree of factor interactions except 
A.E. Specziár and B.E. Turcsányi: Knowl. Manag. Aquat. Ecosyst. 2017, 418, 52

Table 2. Number of pikeperch released $\left(N_{r}\right)$ in five size groups (body mass, $M$ ) and proportion recaptured within 1460 days after release by stocking trials (season, lake area and method of release are indicated) in Lake Balaton, Hungary.

\begin{tabular}{|c|c|c|c|c|c|c|c|c|}
\hline \multicolumn{4}{|c|}{ Stocking trial } & \multicolumn{5}{|c|}{$N_{r}$ (proportion recaptured) by size groups } \\
\hline No. & Season & Area & Method & $M \leq 150 \mathrm{~g}$ & $151-200 \mathrm{~g}$ & $201-250 \mathrm{~g}$ & $251-300 \mathrm{~g}$ & $>300 \mathrm{~g}$ \\
\hline 1. & Autumn & Keszthely & Shore & $52(11.5 \%)$ & $77(23.4 \%)$ & $58(29.3 \%)$ & $44(27.3 \%)$ & $19(31.6 \%)$ \\
\hline 2. & Autumn & Keszthely & Offshore & $48(16.7 \%)$ & $58(19.0 \%)$ & $61(24.6 \%)$ & $55(38.2 \%)$ & $28(21.4 \%)$ \\
\hline 3. & Autumn & Szemes & Shore & $53(13.2 \%)$ & $47(23.4 \%)$ & $66(24.2 \%)$ & $47(25.5 \%)$ & $37(32.4 \%)$ \\
\hline 4. & Autumn & Szemes & Offshore & $66(4.5 \%)$ & $45(15.6 \%)$ & $56(25.0 \%)$ & $56(32.1 \%)$ & $27(22.2 \%)$ \\
\hline 5. & Autumn & Siófok & Shore & $44(6.8 \%)$ & $62(8.1 \%)$ & $53(17.0 \%)$ & $56(19.6 \%)$ & $35(34.3 \%)$ \\
\hline 6. & Autumn & Siófok & Offshore & $51(7.8 \%)$ & $63(14.3 \%)$ & $48(12.5 \%)$ & $59(23.7 \%)$ & $29(24.1 \%)$ \\
\hline 7. & Spring & Keszthely & Shore & $62(17.7 \%)$ & $61(23.0 \%)$ & $56(21.4 \%)$ & $39(20.5 \%)$ & $32(40.6 \%)$ \\
\hline 8. & Spring & Keszthely & Offshore & $74(13.5 \%)$ & $64(18.8 \%)$ & $46(30.4 \%)$ & $50(28.0 \%)$ & $16(43.8 \%)$ \\
\hline 9. & Spring & Szemes & Shore & $59(5.1 \%)$ & $55(9.1 \%)$ & $73(19.2 \%)$ & $38(31.6 \%)$ & $25(48.0 \%)$ \\
\hline 10. & Spring & Szemes & Offshore & $85(1.2 \%)$ & $52(0.0 \%)$ & $56(8.9 \%)$ & $45(20.0 \%)$ & $12(16.7 \%)$ \\
\hline 11. & Spring & Siófok & Shore & $80(2.5 \%)$ & $59(5.1 \%)$ & $57(10.5 \%)$ & $39(15.4 \%)$ & $15(13.3 \%)$ \\
\hline 12. & Spring & Siófok & Offshore & $90(1.1 \%)$ & $64(4.7 \%)$ & $41(9.8 \%)$ & $34(20.6 \%)$ & $21(19.0 \%)$ \\
\hline Total & & & & $764(7.7 \%)$ & 707 (13.9\%) & $671(19.7 \%)$ & $562(25.6 \%)$ & $296(30.1 \%)$ \\
\hline
\end{tabular}

hypothesis (iv) where available degrees of freedom supported evaluation of the main effects only. Separate ANOVAs were run to evaluate effects of the four predictor factors (i) on the recapture rate, (ii) number of days fish spent in lake, (iii) distance between the release and recapture sites, and (iv) shore line length covered by the first 50,75 and $90 \%$ of recaptures based on their distance from the release site. Further, since a preliminary ANOVA indicated that initial fish size was not fully homogeneous across the 12 stocking trials (i.e. season $\times$ lake area $\times$ method of release) - namely, fish $M$ varied little between late autumn (mean $\pm \mathrm{SD}, 214 \pm 71 \mathrm{~g}$ ) and early spring $(198 \pm 72 \mathrm{~g})$ stockings (d.f. $=1 ; 2995, F=41.1, P<0.001)$, but not between sampling areas and methods of release, therefore, the effect of release season on response variables was tested both for the total samples (full models) and for each size group as well in hypotheses (i), (ii) and (iii). Percent recapture data were arcsin square-root transformed, whereas other response variables were $\log _{10}(x+1)$ transformed prior to analysis. In case of significant factor effect $(P<0.05)$, ANOVA was completed with Tukey HDS post hoc tests. In order to ensure comparability across release strategies, only data of fish recaptured within four years (1460 days) after their release were considered in analyses. All the analyses were performed with Statistica 8.0 software (www.statsoft.com).

\section{Results}

\subsection{Reported recapture rate}

Anglers reported recapture data altogether about 522 tagged pikeperch corresponding to $17.4 \%$ total recapture rate during a four year period after the fish had been released (Tab. 1). Factorial ANOVA on the full model (i.e. all four stocking variables included with their second degree interactions) indicated that all stocking season, lake area, method of release and fish size may influence the recapture rate (Tab. 3). However, when effect of fish size was controlled (ANOVA performed for each size group separately) season proved not to be a significant factor anymore. Therefore, it was revealed that: recapture rate increased from Siófok $(13.5 \pm 8.4 \%$; mean \pm SD), through Szemes $(18.9 \pm 12.2 \%)$ to Keszthely $(25.0 \pm 8.7 \%)$ basin; it was slightly higher when fish were released from the shore $(20.4 \pm 11.0 \%)$ than offshore $(17.9 \pm 10.7 \%)$; and recapture rate markedly increased with fish size (from $8.5 \pm 5.9 \%$ in $\leq 150 \mathrm{~g} M$ fish to $29.0 \pm 11.2 \%$ in $>300 \mathrm{~g} M$ fish; Tab. 2) as well.

\subsection{Time in lake}

Recaptures started with five months delay in the late autumn and nearly two months delay after release in early spring stockings (Fig. 2). Furthermore, catches showed a marked seasonality; very few pikeperch were caught during the winter and first half of the spring at water temperatures below $c a .6{ }^{\circ} \mathrm{C}$ water temperature, and majority of recaptures happened between May and October at $11-26^{\circ} \mathrm{C}$ water temperatures (Fig. 2). Recaptures declined markedly in time, especially in the third and fourth years after the stocking (Fig. 2); of the total 522 recaptures $210(40.2 \%)$ happened in the first, $178(34.1 \%)$ in the second, $93(17.8 \%)$ in the third and only $41(7.9 \%)$ in the fourth year of the experiment.

ANOVA of the full model identified effects of season and fish size on the mean time passed between stocking and recapture, and the effect of season proved to be independent of fish size (Tab. 3). Longer time were required to recapture fish stocked in autumn (602 \pm 346 days; mean \pm SD) than in spring (499 \pm 344 days), and smallest fish $(679 \pm 337$ days and $668 \pm 358$ days for $M$ groups $\leq 150 \mathrm{~g}$ and $151-200 \mathrm{~g}$, respectively) were recaptured later than largest ones (476 \pm 325 days and $484 \pm 340$ days for $M$ groups $251-300 \mathrm{~g}$ and $>300 \mathrm{~g}$, respectively).

\subsection{Distribution of fish}

With three exceptions reported from larger southern inflow canals of the lake up to $1 \mathrm{~km}$ upstream, stocked pikeperch remained within Lake Balaton and distributed across its whole 
Table 3. Results of the factorial design ANOVA and Tukey HSD post hoc test (at $P<0.05$ ) on the effect of stocking season, lake area ( $\mathrm{S}=$ Siófok, $\mathrm{Sz}=$ Szemes and $\mathrm{K}=$ Keszthely basin), method (shore $v s$. offshore release) and fish size groups (M1 to M5 represent increasing fish mass) on arcsin square root transformed 1460 days recapture rate by anglers $(\%)$, and $\log _{10}(x+1)$ transformed days spent in lake and distance travelled between release and recapture sites of tagged pikeperch in Lake Balaton. Since size of stocked fish varied between seasons, thus when full model indicated seasonal variability, main effect of season was also tested for each size group separately.

\begin{tabular}{|c|c|c|c|c|c|c|c|c|c|c|c|c|}
\hline & \multicolumn{3}{|c|}{ Recapture rate } & \multirow[t]{2}{*}{ Tukey HSD } & \multicolumn{3}{|c|}{ Days in lake } & \multirow[t]{2}{*}{ Tukey HSD } & \multicolumn{3}{|c|}{ Distance travelled } & \multirow[t]{2}{*}{ Tukey HSD } \\
\hline & d.f. & $F$ & $P$ & & d.f. & $F$ & $P$ & & d.f. & $F$ & $P$ & \\
\hline Season & 1 & 12.9 & 0.001 & Autumn $>$ Spring & 1 & 20.4 & $<0.001$ & Autumn $>$ Spring & 1 & 3.0 & 0.084 & \\
\hline Area & 2 & 24.8 & $<0.001$ & $\mathrm{~K}>\mathrm{Sz}>\mathrm{S}$ & 2 & 1.9 & 0.155 & & 2 & 31.9 & $<0.001$ & $\mathrm{~S}, \mathrm{Sz}>\mathrm{K}$ \\
\hline Method & 1 & 4.6 & 0.041 & Shore $>$ Offshore & 1 & 0.0 & 0.925 & & 1 & 0.1 & 0.716 & \\
\hline Fish size & 4 & 31.9 & $<0.001$ & $\begin{array}{l}\mathrm{M} 5>\mathrm{M} 4>\mathrm{M} 3 \\
>\mathrm{M} 2>\mathrm{M} 1\end{array}$ & 4 & 4.3 & 0.002 & M1, M2 > M4, M5 & 4 & 3.2 & 0.014 & $\begin{array}{l}\text { M5, M4, } \\
\text { M3 > M1 }\end{array}$ \\
\hline Season $\times$ area & 2 & 4.9 & 0.014 & & 2 & 2.2 & 0.115 & & 2 & 0.3 & 0.730 & \\
\hline Season $\times$ method & 1 & 0.9 & 0.343 & & 1 & 0.7 & 0.392 & & 1 & 0.1 & 0.766 & \\
\hline Area $\times$ method & 2 & 6.4 & 0.005 & & 2 & 0.3 & 0.759 & & 2 & 0.2 & 0.860 & \\
\hline Season $\times$ fish size & 4 & 1.9 & 0.144 & & 4 & 0.1 & 0.977 & & 4 & 0.7 & 0.595 & \\
\hline Area $\times$ fish size & 8 & 1.0 & 0.478 & & 8 & 1.0 & 0.449 & & 8 & 2.4 & 0.013 & \\
\hline Method $\times$ fish size & 4 & 1.6 & 0.196 & & 4 & 0.4 & 0.821 & & 4 & 0.9 & 0.463 & \\
\hline Error & 30 & & & & 492 & & & & 491 & & & \\
\hline \multicolumn{13}{|c|}{ Main effect of season by size groups } \\
\hline $\mathrm{M} 1(\leq 150 \mathrm{~g})$ & $1 ; 7$ & 4.0 & 0.085 & & $1 ; 54$ & 1.5 & 0.232 & & & & & \\
\hline M2 (151-200g) & $1 ; 7$ & 4.6 & 0.070 & & $1 ; 93$ & 6.5 & 0.012 & Autumn $>$ Spring & & & & \\
\hline M3 (201-250g) & $1 ; 7$ & 4.4 & 0.073 & & $1 ; 127$ & 7.7 & 0.006 & Autumn $>$ Spring & & & & \\
\hline M4 (251-300 g) & $1 ; 7$ & 3.3 & 0.110 & & $1 ; 139$ & 6.8 & 0.010 & Autumn $>$ Spring & & & & \\
\hline M5 $(>300 \mathrm{~g})$ & $1 ; 7$ & 0.1 & 0.804 & & $1 ; 84$ & 4.1 & 0.047 & NS & & & & \\
\hline
\end{tabular}

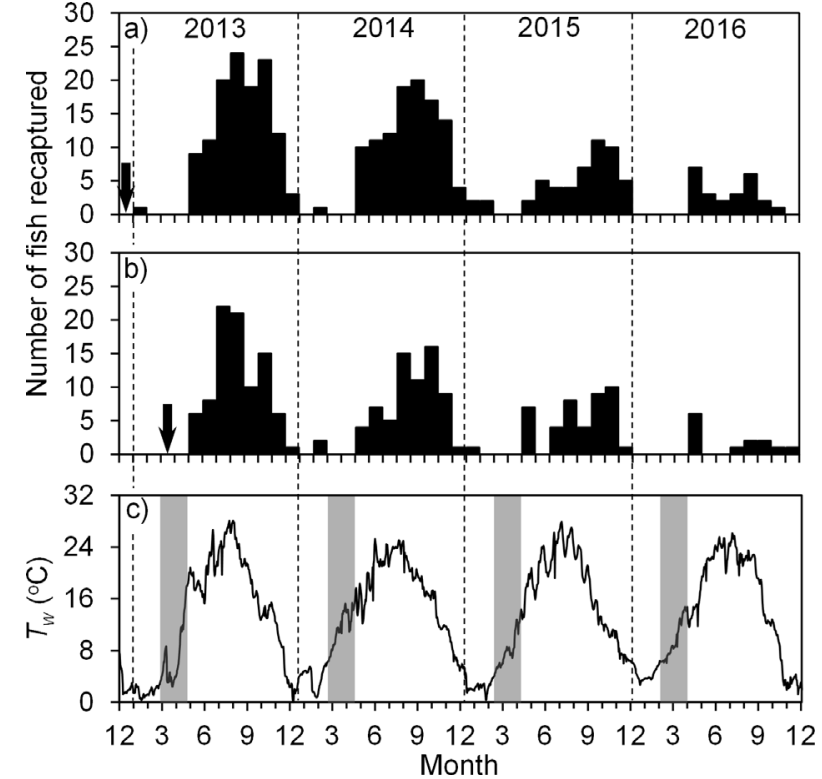

Fig. 2. Seasonal recapture dynamics of pikeperch stocked in autumn (a) and spring (b) in relation to water temperature $\left(T_{w}\right)(\mathrm{c})$ in Lake Balaton, Hungary. In each stocking season altogether 1500 tagged fish were released (Tab. 1). Stocking events are indicated by arrows and sanctuary season by grey shading. area. Offshore boat fishing provided most $(82 \%)$ of the recaptures, while 74 of the 93 recaptures reported by shore anglers happened from deep water moles.

Individual fish showed remarkable differences in their movements; some specimens travelled $30-60 \mathrm{~km}$ within 60 150 days, while others were recaptured $<3 \mathrm{~km}$ distance from their release site even after more than three years in the lake (Fig. 3). There was no relationship between the distance between the release and recapture locations and the time fish spent in liberty (Spearman rank correlation, d.f. $=15-59$, $r_{s}=-0.093 \pm 0.232, P=0.239-0.766$ for the 12 individual trials). Therewith, the mean distance of recaptures from the release site varied significantly between stocking areas and size groups, but not between seasons and methods of release (Tab. 3). Namely, pikeperch released at Siófok $(22.5 \pm 17.7 \mathrm{~km} ;$ mean \pm SD) and Szemes $(19.0 \pm 10.2 \mathrm{~km})$ were recaptured at higher mean distance from the stocking site than those released at Keszthely $(11.2 \pm 10.1 \mathrm{~km})$, and fish belonging to the three largest size groups (17.7 \pm 13.8 , $18.1 \pm 14.4$ and $17.1 \pm 13.2 \mathrm{~km}$ in the $>300,251-300$ and 200-251 g $M$ groups, respectively) on average travelled to more distant habitats than those of the smallest size class $(10.6 \pm 7.2 \mathrm{~km}$ in the $\leq 150 \mathrm{~g} M$ class $)$.

Lake area covered by 50 and 75 , but not $90 \%$ of recaptures also showed some variability across stoking locations; and recaptures dispersed in space more when fish were released at Siófok or Szemes than at Keszthely (Tab. 4, Fig. 4). In turn, our 


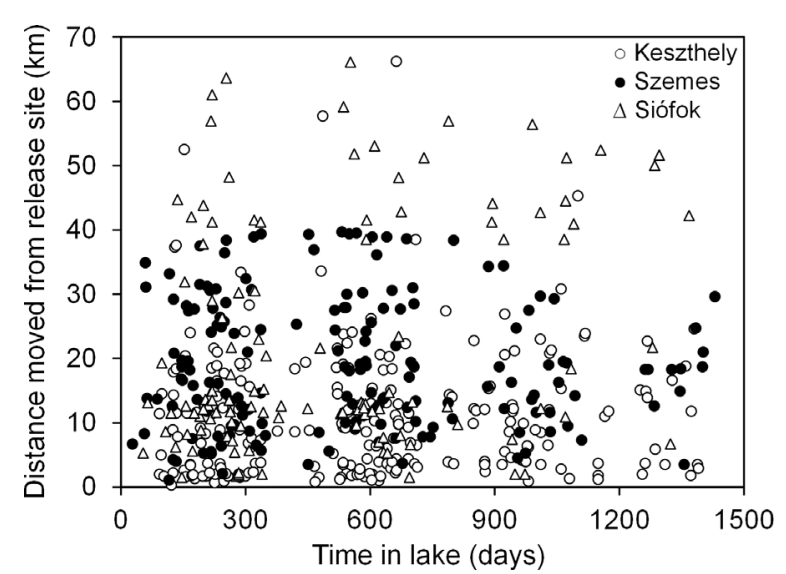

Fig. 3. Distance between the release (i.e. Keszthely, Szemes and Siófok) and recapture locations of stocked pikeperch in relation to days spent in Lake Balaton, Hungary. Note that Szemes is located approximately at the middle of the longitudinal axis of the lake and thus fish released there can move away maximum $40 \mathrm{~km}$.

analysis did not reveal any significant season and fish size related variability in recapture data in this regard. Finally, it was salient that consistently much more (on average 3.8 times more) of fish released at Szemes moved towards Keszthely than Siófok $\left(\chi^{2}=3.8-35.0, P<0.05\right.$ for the four relevant trials).

\section{Discussion}

In waters with intensive catch-and-take recreational fishery stocking of the most preferred game fishes is usually necessary for maintaining ecological equilibrium and a satisfactory catching efficiency. From the point of view of angling, when appropriate age classes and annual stocking quotas have already been allocated relative efficiency of alternative release strategies can be rated by the ratio of fish recaptured by anglers and spatial range of recaptures. Accordingly we implemented a tagging experiment to evaluate how 60 different release setups (i.e. two seasons $\times$ three lake areas $\times$ two methods $\times$ five size classes) influence yearling pikeperch stocking efficiency in recreational Lake Balaton. Total four years (reported) recapture rate $(17.4 \%)$ was similar to the $17.5 \%$ two years recapture rate of common carp in Lake Balaton (Specziár and Turcsányi, 2014). However, wild-born, tagged pikeperch were recaptured by fishermen at a higher rate of $20.6 \%$ in a Baltic Archipelago Area (Saulamo and Thoresson, 2005) and 30.4\% in Lake Mälaren, Sweden (Andersson et al., 2015). In line with our presumption, results proved that influence of pikeperch stocking on anglers captures varies between stocking seasons and stocking areas as well as it depends on the size of fish at release in Lake Balaton. However, some of our specific predictions were not approved and observed patterns also deviated in some respect from those described in other studies on pikeperch and other fish species.

Variances of recapture rate are strongly related to survival of the stocked fish. When pond or hatchery reared, naive fish are released into wild habitats they encounter a variety of stressful situations and thus may be exposed to considerable mortality (Saloniemi et al., 2004). Contrary to our expectation, we did not find a direct relationship between the recapture rate and the stocking season in pikeperch. This is surprising because size-dependent winter mortality of juveniles is one of the key factors in year-class strength formation of pikeperch (Ruuhijärvi et al., 1996; Lappalainen et al., 2000) and closely related walleye Sander vitreus (Johnson et al., 1996), and is likely to be even more important in freshly stocked fish which need to spend extra energies for foraging appropriate habitat in unknown environment (Bolland et al., 2009; Buckmeier et al., 2005). Accordingly, several studies on different species concluded that fish stocked in spring and summer have better chance to survive, and thence to be recaptured, than those released just before the winter (Templeton, 1971; Strange and Kennedy, 1979; Kennedy et al., 1982; Vostradovský, 1991). This general pattern was observed in the stocked common carp in Lake Balaton as well (Specziár and Turcsányi, 2014). The reason why pikeperch responded differently in this study cannot be clearly ascertained, but two probable causes could be identified. We assume that since pikeperch is active and feeds through the winter (Popova and Sytina, 1977), may be less sensitive to winter, compared for instance to common carp, given that feeding conditions are satisfactory. Moreover, we stocked relatively large pikeperch yearlings (170-305 mm SL) which have much more energy reserves than those of the first wintering natural recruitment (60-100 mm SL; Specziár, 2010) and represent fully switched piscivores which already had escaped from early life feeding bottleneck in Lake Balaton (Specziár, 2005, 2011). Briefly, since both abundant largesized, benthic crustaceans and small-sized, slender benthic prey fishes are lacking, pikeperch is exposed to a serious feeding bottleneck effect and cannibalism between 40 and $120 \mathrm{~mm} S L$ in Lake Balaton. On the other hand, fish overwintered in ponds till spring stocking also had lost detectable proportion ( $c a .7 .5 \%$ ) of their mass and accordingly were likely less fit than those stocked before the winter. As we predicted, recapture rate increased markedly with fish size at stocking, which is not surprising because most ecological processes influencing mortality of fish are size dependent (Sogard, 1997; Schultz and Conover, 1999). In ontogenetic diet switchers like the pikeperch is (Buijse and Houthuijzen, 1992; Specziár, 2005), stocking size could be even more important and to avoid dietary bottleneck effect should be adjusted to the size distribution of the potential prey in the target ecosystem (Buijse and Houthuijzen, 1992; Fielder, 1992). Our finding on the importance of fish size at release also coincides with results of other stocking experiments using either pond reared or wild captured fish (e.g. Fielder, 1992; Johnson et al., 1996; Kristiansen et al., 2000; Michaletz et al., 2008; Specziár, 2010; but see Specziár and Turcsányi, 2014). Moreover, recapture rate also varied between lake areas following the increasing trophic gradient from the Siófok towards the Keszthely basin (Istvánovics et al., 2007). This phenomenon may be as good related to better survival of stocked pikeperch in more food rich environment which is also supported by the same main trend of fish biomass in Lake Balaton (Bíró, 1997; Specziár, 2010). Availability of appropriate food was found to be critical for stocking success in several studies. For instance, based on his experiences on walleye fry and fingerling stockings in Lower Lake Oahe (South Dakota, USA), Fielder (1992) suggested that selection 
Table 4. Results of the ANOVA on the effect of stocking season, lake area $(\mathrm{S}=\mathrm{Sió} f o k, \mathrm{Sz}=$ Szemes and $\mathrm{K}=\mathrm{Keszthely}$ basin) and method (shore $v s$. offshore release) on $\log _{10}(x+1)$ transformed shore line length data covered by the first 50,75 and $90 \%$ of pikeperch recaptures according to their distance from the release site in Lake Balaton, Hungary. Results of the Tukey HDS post hoc tests are reported for significant single factor effects (at $P<0.05$ ) in total shore line. Note that the effect of fish size could not be tested due to limited sample sizes.

\begin{tabular}{|c|c|c|c|c|c|c|c|c|}
\hline & \multirow[t]{2}{*}{ d.f. } & \multicolumn{2}{|c|}{ Southern shore line } & \multicolumn{2}{|c|}{ Northern shore line } & \multicolumn{2}{|c|}{ Total shore line } & \multirow[t]{2}{*}{ Tukey HDS } \\
\hline & & $F$ & $P$ & $F$ & $P$ & $F$ & $P$ & \\
\hline \multicolumn{9}{|c|}{$50 \%$ of recaptures } \\
\hline Season & 1 & 1.4 & 0.281 & 0.0 & 0.834 & 0.3 & 0.599 & \multirow{4}{*}{$\mathrm{S}, \mathrm{Sz}>\mathrm{K}$} \\
\hline Area & 2 & 10.6 & 0.007 & 44.9 & $<0.001$ & 34.8 & $<0.001$ & \\
\hline Method & 1 & 3.1 & 0.123 & 0.0 & 0.960 & 1.2 & 0.307 & \\
\hline Error & 7 & & & & & & & \\
\hline \multicolumn{9}{|c|}{$75 \%$ of recaptures } \\
\hline Season & 1 & 0.0 & 0.949 & 4.4 & 0.075 & 1.5 & 0.257 & \multirow{4}{*}{$\mathrm{S}>\mathrm{K}$} \\
\hline Area & 2 & 1.7 & 0.246 & 17.9 & 0.002 & 11.6 & 0.006 & \\
\hline Method & 1 & 0.1 & 0.824 & 2.2 & 0.178 & 0.7 & 0.431 & \\
\hline Error & 7 & & & & & & & \\
\hline \multicolumn{9}{|c|}{$90 \%$ of recaptures } \\
\hline Season & 1 & 3.4 & 0.108 & 0.1 & 0.802 & 1.0 & 0.346 & \\
\hline Area & 2 & 0.2 & 0.844 & 0.5 & 0.653 & 0.9 & 0.440 & \\
\hline Method & 1 & 3.3 & 0.110 & 1.9 & 0.212 & 0.0 & 0.882 & \\
\hline Error & 7 & & & & & & & \\
\hline
\end{tabular}

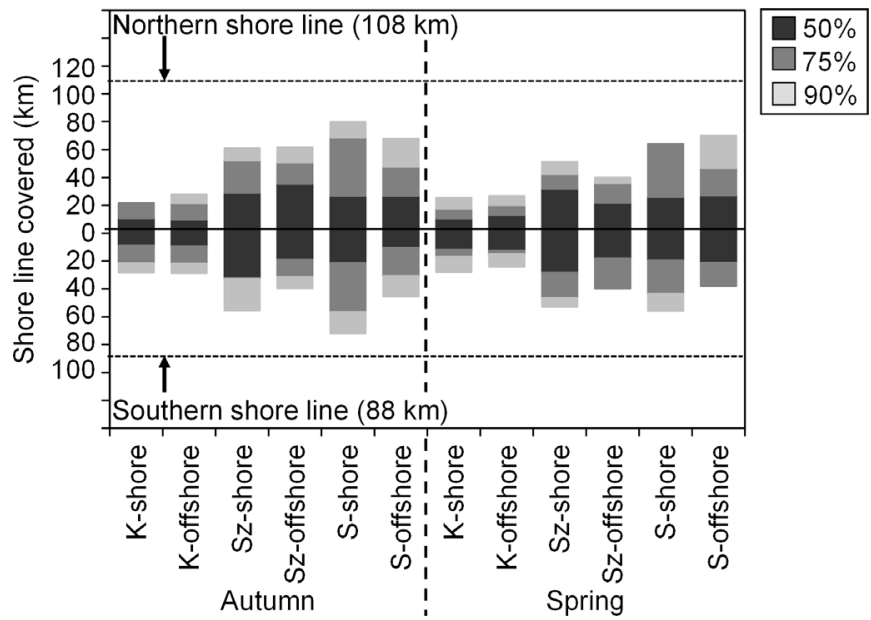

Fig. 4. Length $(\mathrm{km})$ of northern and southern shore lines (i.e. extent of fishing area) covered by the first 50,75 and $90 \%$ of pikeperch recaptures according to their distances from the release site in Lake Balaton, Hungary (for statistics see Tab. 3).

of timing and location of stocking should be adjusted as much as it is possible to seasonal peaks of the food resource in the new habitat. However, since we do not have proper data on the geographical distribution of angling effort, thence we cannot unequivocally prioritize this explanation. Finally, the narrow difference in the recapture rate in favour of shore releases over offshore releases could bear little importance in the practice. Since pikeperch is basically an offshore species which moves to the littoral zone only occasionally following seasonal and diurnal movements of their prey fish shoals (Specziár et al.,
2013; Andersson et al., 2015), offshore releases could be logical alternatives but are more complicated (i.e. fish should be restowed one more time) and time consuming, and correspondingly involve more transport related risk ( $c f$. Paragamian and Kingery, 1992; Hansson et al., 1997).

Pikeperch recaptures depleted at a rate of $49 \%$ year $^{-1}$ from the second year after stocking $\left(47 \%\right.$ year $^{-1}$ for the whole observation period) when majority of released fish supposedly reached legal catch size in Lake Balaton. Actual depletion of recaptures was only slightly slower than in our preliminary studies during 2003-2010 (56\% year $\left.{ }^{-1}\right)$ when commercial fishery was also still in operation (Specziár, 2010). Tag loss and natural mortality might also contribute to this pattern, but in our opinion most of this depletion could be related to the high angling pressure on pikeperch in Lake Balaton. Although, this result indicates a considerably lower utilization rate in pikeperch by anglers compared to common carp, recaptures of which species depleted at an enormous rate of $89 \%$ year $^{-1}$ (Specziár and Turcsányi, 2014), the situation is not so bright from ecological and practical aspects. Since recruitment of the pikeperch population is still primarily depends on its natural reproduction and stockings add only a minor contribution (supposedly not more than $10 \%$ of the total recruitment at the present; Specziár, 2010), compared to the common carp which abundance could be maintained by regular stockings (more than $95 \%$ of the abundance comes from stocking; Specziár, 2010; Specziár and Turcsányi, 2014), it is the pikeperch which population management requires the highest prudentiality. The high rate of angling utilization at the one side and the limited present stocking capacity (i.e. amount of annually available pond reared yearlings) on the other side could represent a high risk to the stability of the pikeperch population and consequentially ecosystem equilibrium of Lake Balaton. 
Therefore, a sustainable pikeperch stock management should find a solution for how to decrease fishery mortality and improve natural recruitment of the pikeperch stock without depressing satisfaction of anglers. Such action should include implementation of more flexible regulations of angling quotas, sanctuary seasons and restricted areas based on results of annual stock monitoring and exact fisheries statistics about catches and effort as well as elaboration of a more effective pikeperch breeding program to provide more large sized yearlings for stocking.

Not surprisingly it took a longer mean time to recapture pikeperch stocked at the beginning of the out of angling season, in December than in the middle of the out of season period, in March. However, contrary to the two to three summers old stocked common carp which is highly exposed to catch-and-take fishery forthright after its spring and summer stockings (Specziár, 2010; Specziár and Turcsányi, 2014), stocked one summer old pikeperch needs longer time to attain its legal size, and therefore, has more time to acclimatize and disperse in Lake Balaton before could be taken by anglers. Accordingly, the area and method of stocking should not have any marked influence on the timing of recaptures, which was proved by the results as well. Analyses revealed that the larger a pikeperch is at release the more rapid its recapture will be. This relationship is in line with the size-selectivity of angling methods of piscivorous fishes (i.e. gape-limited catchability by both live prey fish and lures; Arlinghaus et al., 2008; Specziár, 2011) and that the smaller a pikeperch is at release the more time it needs to grow into angling gears.

Since anglers are active along the whole shore line (at least at coarse scale), it is very important to know to what extent stocked fish disperse in Lake Balaton. Results about the movement and distribution of stocked pikeperch deviate from our hypotheses in some respect and indicate that dispersal of pikeperch differs also from that of the common carp (Specziár and Turcsányi, 2014). Namely, season of release did not influence neither the mean distance between stocking and recapture sites nor the area over which majority of recaptures (i.e. 50,75 or $90 \%$ of recaptures closest to the release site) distributed. As we argue above, this could be because stocked pikeperch need longer time to recruit into angling gears than common carp, and thence may disperse to a similar extent regardless the season of release. With no effect from the method of release, pikeperch stocked to most productive Keszthely basin dispersed significantly the least. This finding coincides with observations on common carp (Specziár and Turcsányi, 2014) as well and indicates that stocked fish are more likely to undertake extensive post-stocking exploring movements if released to suboptimal habitats like the oligotrophic Siófok and Szemes basins of Lake Balaton are. The importance of habitat quality in dispersal of stocked pikeperch is also supported by that fish released at the central part of the lake, Szemes, moved mainly towards the more productive areas. Moreover, since the distance between locations of release and recapture did not increase with the time elapsed from stocking, it is likely that most of the dispersal happened rapidly, within few months, and before the mass recaptures started. There is a general agreement across a wide-range of studies that wild pikeperch show marked site fidelity, usually remain within a few kilometres range and even are capable for homing if relocated (Keskinen et al., 2005;
Andersson et al., 2015). However, in line with the present results, it is also known that stocked, naive, pond-reared fish could be more active especially at the beginning and travel substantially longer distances (Bolland et al., 2009). For instance, present results demonstrate that pond reared pikeperch yearlings released into a large lake of $72 \mathrm{~km}$ length and $593 \mathrm{~km}^{2}$ area at as few as only two to three sites are able to populate the entire lake. Fish size had less effect on fish movements than expected and only the smallest size group deviated from the general dispersal pattern by moving less far from the release site, which could be explained by their less physical power.

The uneven distribution of pikeperch recaptures at small scale (i.e. considering ca. $5 \mathrm{~km}$ shore sections) could be explained by two reasons. First, although the offshore area of Lake Balaton seems to be a homogeneous habitat at first sight, yet minor differences in the substrate properties and water depth occur there. Areas with harder substrate (i.e. sand, marl or rocky substrate, compared to the characteristic muddy lake sediment) and slightly deeper water (even few $10 \mathrm{~cm}-\mathrm{s}$ alterations may count) are preferred habitats of pikeperch, and thus, are popular angling places. Second, at local scale angling facilities are unevenly distributed and the angling effort is concentrated in the vicinity of boat harbours (mainly because the use of explosion engines is not allowed for recreational use in Lake Balaton and boats may be powered only by rowing, electric drive or sailing), moles and free shore sections. Nevertheless, these local patterns do not influence the above discussed lake level trends in the distribution and recapture rate of stocked pikeperch. Therefore, since physical habitat characteristics including water depth as well do not vary substantially between lake basins, we argue that spatial differences in the distribution and recapture rate of stocked pikeperch could primarily be related to the effect of withinlake nutrient gradient.

To conclude, the present study provides useful information about influences of various stocking strategies on pikeperch recaptures by anglers. Based on the results, we suggest that autumn stocking should be preferred over spring ones because it provides the same recapture rate but with coasty procedures and mortality of pond wintering be saved. It is also concluded that the larger the fish stocked is, the higher the chance it will be recaptured, and accordingly, present results could serve as a basis of economic calculations between breading coast and return (recapture probability) of pikeperch stocking programs. In Lake Balaton, the more expensive and risky offshore stocking provides no benefits neither in recapture rate nor in dispersal compared to direct releases from the tanker truck at the shore. We found that stocked pikeperch disperse over extended areas from the release site, and thus concentrated stocking at one or few sites could be appropriate in the oligotrophic Siófok and Szemes basins with large sized $(>150 \mathrm{~g} \mathrm{M}$ ) yearlings. Whereas due to the weaker dispersal of fish, it is recommended that stocking quotas should be distributed along multiple sites in the mesotrophic part of Lake Balaton (Keszthely and Szigliget basins) and when only small sized $(\leq 150 \mathrm{~g} M)$ yearlings are available. Results also indicate that to improve total recaptures, that is the angling success in oligotrophic parts of the lake would require much more intensive stocking there than in the mesotrophic areas and would markedly decrease overall coast efficiency of the stocking program. 
Acknowledgements. The authors would like to thank Ferenc Bertalan, Géza Dobos, János Fléger, Miklós Ihász and Róbert Tatár for their contribution in tagging and releasing pikeperch into Lake Balaton, and anglers reporting correct data on the capture of tagged fish. Fish, tags and rewarding of recaptures was founded by the Balaton Fish Management Non-Profit Ltd, while analysis of data and writing of the paper was supported by the GINOP 2.3.2-15-2016-00004 project.

\section{References}

Abdolmalaki S, Psuty I. 2007. The effects of stock enhancement of pikeperch (Sander lucioperca) in Iranian coastal waters of the Caspian Sea. ICES J Mar Sci 64: 973-980.

Andersson M, Degerman E, Persson J, Ragnarsson-Stabo H. 2015. Movements, recapture rate and length increment of tagged pikeperch (Sander lucioperca) - a basis for management in lakes. Fish Manag Ecol 22: 450-457.

Arlinghaus R, Klefoth T, Kobler A, Cooke SJ. 2008. Size selectivity, injury, handling time, and determinants of initial hooking mortality in recreational angling for northern pike: the influence of type and size of bait. N Am J Fish Manag 28: 123-134.

Balfry S, Welch DW, Atkinson J, Lill A, Vincent S. 2011. The effect of hatchery release strategy on marine migratory behaviour and apparent survival of Seymour River steelhead smolts (Oncorhynchus mykiss). PLoS ONE 6: e14779.

Bíró P. 1997. Temporal variation in Lake Balaton and its fish populations. Ecol Freshw Fish 6: 196-216.

Bolland JD, Cowx IG, Lucas MC. 2009. Dispersal and survival of stocked cyprinids in a small English river: comparison with wild fishes using a multi-method approach. J Fish Biol 74: 2313-2328.

Booth AJ, Weyl OLF. 2008. Retention of T-bar anchor and dart tags by a wild population of African sharptooth catfish, Clarias gariepinus. Fish Res 92: 333-339.

Buckmeier DL, Betsill RK, Schlechte JW. 2005. Initial predation of stocked fingerling largemouth bass in Texas Reservoir and implications for improving stocking efficiency. $N$ Am J Fish Manag 25: 652-659.

Buijse AD, Houthuijzen RP. 1992. Piscivory, growth, and sizeselective mortality of age 0 pikeperch (Stizostedion lucioperca). Can J Aquat Sci 49: 894-902.

Craig JF. 2000. Percid fishes: systematics, ecology and exploitation. Oxford, Blackwell.

Fielder DG. 1992. Evaluation of stocking walleye fry and fingerlings and factors affecting their success in lower Lake Oahe, South Dakota. N Am J Fish Manag 12: 336-345.

Hansen MM. 2002. Estimating the long-term effects of stocking domesticated trout into wild brown trout (Salmo trutta) populations: an approach using microsatellite DNA analysis of historical and contemporary samples. Mol Ecol 11: 1003-1015.

Hansson S, Arrhenius F, Nellbring S. 1997. Benefits from fish stocking - experiences from stocking young-of-the-year pikeperch, Stizostedion lucioperca L. to a bay in the Baltic Sea. Fish Res 32: 123-132.

Hickley P, Chare S. 2004. Fisheries for non-native species in England and Wales: angling or the environment? Fish Manag Ecol 11: 203-212.

Istvánovics V, Clement A, Somlyódy L, Specziár A, László G, Padisák J. 2007. Updating water quality targets for shallow Lake Balaton (Hungary), recovering from eutrophication. Hydrobiologia 581: 305-318.

Johnson BM, Vogelsang M, Stewart RS. 1996. Enhancing a walleye population by stocking: effectiveness and constraints on recruitment. Ann Zool Fennici 33: 577-588.
Kennedy GJA, Strange CD, O’Neill GO. 1982. Tagging studies on various age classes of brown trout (Salmo trutta L.). Fish Manag 13: 33-41.

Keskinen T, Pääkkönen JPJ, Lilja J, Marjomäki TJ, Karjalainen J. 2005. Homing behaviour of pikeperch (Sander lucioperca) following experimental transplantation. Boreal Environ Res 10: 119-124.

Kristiansen TS, Otterå H, Svåsand T. 2000. Size-dependent mortality of juvenile Atlantic cod, estimated from recaptures of released reared cod and tagged wild cod. J Fish Biol 56: 687-712

Lappalainen J, Erm V, Kjellman J, Lehtonen H. 2000. Size-dependent winter mortality of age-0 pikeperch (Stizostedion lucioperca) in Pärnu Bay, the Baltic Sea. Can J Fish Aquat Sci 57: 451-458.

Lappalainen J, Milardi M, Nyberg K, Venäläinen A. 2009. Effects of water temperature on year-class strengths and growth patterns of pikeperch (Sander lucioperca (L.)) in the brackish Baltic Sea. Aquat Ecol 43: 181-191.

Michaletz PH, Wallendorf MJ, Nicks DM. 2008. Effects of stocking rate, stocking size and angler catch inequality on exploitation of stocked channel catfish in small Missouri impoundments. N Am $J$ Fish Manag 28: 1486-1497.

Paragamian VL, Kingery R. 1992. A comparison of walleye fry and fingerling stockings in three rivers in Iowa. N Am J Fish Manag 12: 313-320.

Patterson WF, Sullivan MG. 2013. Testing and refining the assumptions of put-and-take rainbow trout fisheries in Alberta. Hum Dimens Wildl 18: 340-354.

Popova OA, Sytina LA. 1977. Food and feeding relations of Eurasian perch (Perca fluviatilis) and pikeperch (Stizostedion lucioperca) in various waters of the USSR. J Fish Res Bd Can 34: 1559-1570.

Ruuhijärvi J, Salminen M, Nurmio T. 1996. Releases of pikeperch (Stizostedion lucioperca (L.)) fingerlings in lakes with no established pikeperch stock. Ann Zool Fennici 33: 553-567.

Sackett DK, Catalano M. 2017. Spatial heterogeneity, variable rewards, tag loss, and tagging mortality affect the performance of mark-recapture designs to estimate exploitation: an example using red snapper in the northern Gulf of Mexico. NAm J Fish Manag 37: $558-573$.

Saloniemi I, Jokikokko E, Kallio-Nyberg I, Jutila E, Pasanen P. 2004. Survival of reared and wild Atlantic salmon smolts: size matters more in bad years. ICES J Mar Sci 61: 782-787.

Saulamo K, Thoresson G. 2005. Management of pikeperch migrating over management areas in a Baltic Archipelago area. Ambio 34: $120-124$.

Schultz ET, Conover DO. 1999. The allometry of energy reserve depletion: test of a mechanism for size-dependent winter mortality. Oecologia 119: 474-483.

Sogard SM. 1997. Size-selective mortality in the juvenile stage of teleost fishes: a review. Bull Mar Sci 60: 1129-1157.

Specziár A. 2005. First year ontogenetic diet patterns in two coexisting Sander species, S. lucioperca and S. volgensis, in Lake Balaton. Hydrobiologia 549: 115-130.

Specziár A. 2010. Fish fauna of Lake Balaton: stock composition, living conditions of fish and directives of the modern utilization of the fish stock. Acta Biol Debr Suppl Oecol Hung 23 (Hydrobiol Monogr) 2: 7-185 (in Hungarian with an English summary).

Specziár A. 2011. Size-dependent prey selection in piscivorous pikeperch Sander lucioperca and Volga pikeperch S. volgensis shaped by bimodal prey size distribution. J Fish Biol 79: 1895-1917.

Specziár A, Erös T. 2016. Freshwater resources and fisheries in Hungary. In: Craig JF, ed. Freshwater fisheries ecology. Wiley, Oxford, pp. 196-200.

Specziár A, Turcsányi B. 2014. Effect of stocking strategy on distribution and recapture rate of common carp Cyprinus carpio L., 
A.E. Specziár and B.E. Turcsányi: Knowl. Manag. Aquat. Ecosyst. 2017, 418, 52

in a large and shallow temperate lake: implications for recreational put-and-take fisheries management. $J$ Appl Ichthyol 30: 887-894.

Specziár A, György ÁI, Erős T. 2013. Within-lake distribution patterns of fish assemblages: the relative roles of spatial, temporal and random environmental factors in assessing fish assemblages using gillnets in a large and shallow temperate lake. J Fish Biol 82: 840-855.

Strange CD, Kennedy GJA. 1979. Yield to anglers of spring and autumn stocked, hatchery reared and wild, brown trout. Fish Manag 10: 45-52.

Stuart IG, Jones MJ. 2006. Movement of common carp, Cyprinus carpio, in a regulated lowland Australian river: implications for management. Fish Manag Ecol 13: 213-219.

Templeton RG. 1971. An investigation of the advantages of autumn and spring stocking with brown trout in a Yorkshire reservoir. Fish Manag 1: 35-43.
Vandersteen W, Biro P, Harris L, Devlin R. 2012. Introgression of domesticated alleles into a wild trout genotype and the impact on seasonal survival in natural lakes. Evol Appl 5: 76-88.

Vostradovský J. 1991. Carp (Cyprinus carpio L.) "put-and-take" fisheries in the management of angling waters in Czechoslovakia. In: Cowx IG, ed. Catch effort sampling strategies: their application in freshwater fisheries management. Fishing new books. Blackwell, Oxford, pp. 100-107.

Weiperth A, Ferincz Á, Kováts N, Hufnagel L, Staszny Á, Keresztessy K, Szabó I, Tátrai I, Paulovits G. 2014. Effect of water level fluctuation on fishery and angler's catch data of economically utilised fish species of Lake Balaton between 19012011. Appl Ecol Environ Res 12: 221-249.

Young GC, Wise BS, Ayvazian SG. 1999. A tagging study on tailor (Pomatomus saltatrix) in Western Australian waters: their movement, exploitation, growth and mortality. Mar Freshw Res 50: 633-642.

Cite this article as: Specziár A, Turcsányi B. 2017. Management of pikeperch stocking in Lake Balaton: effect of season, area, fish size and method of release on the rate and distribution of recaptures. Knowl. Manag. Aquat. Ecosyst., 418, 52. 